\title{
LEXICAL, SEMANTIC AND PRAGMATIC CHARACTERISTICS OF THE MANIPULATIVE STRATEGY IN THE AUTHORITARIAN ENGLISH DISCOURSE OF CHILDREN
}

\section{Soloshchuk Liudmyla ${ }^{1}$ \\ Pakharenko Anastasiia ${ }^{2}$}

DOI: https://doi.org/10.30525/978-9934-571-78-7_32

Abstract. The purpose of this paper is to identify the principles of manipulation in the authoritarian English discourse of children. The study summarizes the latest findings of the research on discourse manipulation of adult interlocutors and aims at the defining of the manipulative discourse of children. It highlights the characteristic lexical, semantic and pragmatic features of the discourse in which the children's manipulation is presented. Their variability in different communicative situations is traced. The methodology of the study is based on the anthropocentric approach in linguistics. The research started with selecting the dialogic discourse fragments from literary pieces by British and American writers of the 20th and early 21 st centuries and movie scripts in which manipulation strategy implemented by children aged between 4 and 16 is presented. At the second stage, the method of discourse analysis was applied in order to classify the fragments into related categories based on the age of interlocutors and the degree of their relation to each other. The categories in question appeared to be the configurations "pre-school manipulative child - pre-school child", "pre-school manipulative child - middle-/high-school child", "middle-/ high-school manipulative child - pre-school child", "middle-/high-school manipulative child - middle-/high-school child". At the third stage, discourse manipulation was defined as a communicative practice in which the influence is exerted by a child over his/her interlocutor by a number of verbal and nonverbal resources, usually against the recipient's will. It is aimed at the indirect controlling and modifying the opponent's cognitive and behavioral activities according to the manipulative speaker's wishes

\footnotetext{
${ }^{1}$ Doctor of Philology, Full Professor at the English Philology Department,

V.N. Karazin Kharkiv National University, Ukraine

${ }^{2}$ Lecturer at the English Philology Department,

V.N. Karazin Kharkiv National University, Ukraine
} 


\section{Chapter «Philological sciences»}

and intentions. Eventually, through the pragmatic analysis the discourse tactics which lie within the scope of the manipulative strategy were singled out. The latter is presented by the tactics of appealing to the rational and emotional spheres of the addressee, including the involvement a third person for intermediated manipulative influence (techniques of shifting the responsibility; generalization; negative reference to a third person or referring to him through relevant sources or artifacts); the tactic of creating an image of a reward; the tactic of pretended kindness. The results of the analysis of the lexical and semantic areas of manipulation showed that the verbal and nonverbal means which implement manipulation in the abovementioned interlocutors' configurations vary according to each situation in particular. The findings proved that the complexity of the discourse tactics chosen varies depending on the age of the manipulative child and that of his/her interlocutor's. The older the recipient is, the more complicated the manipulative strategy implementation is.

\section{Introduction}

Constantly being in a society which is continually developing provides a personality with information streams which influence him/her in a certain way. Following O. V. Shelestjuk, speech influence means "conveying information from the speaker to the recipient in the process of communication in the oral/written form with the help of linguistic, paralinguistic or extralinguistic symbolic means. It is driven by the addresser's conscious or subconscious intentions and the goals of communication - meaningful, communicative or informative, as well as presuppositions and a specific sign situation" [55, p. 38].

In a narrower sense speech influence may differ through the speaker's particular meaningful goals which are aimed either at encouraging him to act in a particular way, change the attitude of the addressee to the addresser, modify his world perception or alter his rational, emotional and psychophysical state through the use of verbal and nonverbal means of communication.

Speech influence is based on several criteria: a) the type of the addresseraddressee interaction. It can be explicit and implicit (the latter presupposes no direct expression of the addresser's will and implies decoding of perception and subconscious perception of the implicit contents) [51, p. 37-41]; b) the addressee's awareness/unawareness of the influence (conscious - 
intentional and nonconscious - unintentional). Exerting conscious influence, the addresser aims at making the addressee react verbally, physically or emotionally; exerting influence over the addressee without any realization of it, the addresser does not plan to get a certain result or reaction from the addressee [62, p. 157].

The direct influence on the recipient is exerted through the participant of the conversation applying strategies which implement his intentions and communicative objectives. Opting for a particular strategy and its speech implementation directly depend on such pragmatic factors as the degree of the speakers' acquaintance, their social role, age, national and cultural identity, their knowledge of the cognitive and psychological spheres of the addressee, i.e. his communicative experience and expertise [2, p. 158-160].

Discourse studies interpret a strategy as "a complex of speech $[24$, p. 54] / non-speech actions" [19, p. 51], "the pragmalinguistic principle of actualizing illocutionary meanings" [53, p. 35], including the speaker communicative intention /plan $[2$, p. $155 ; 65$, p. 72], which appears to be based on satisfying one's own individual needs and desires due to the social experience, and objectivizing this experience in language [16, p. 85].

As the term "speech influence" is incredibly broad, there traditionally are singled out such subcategories/kinds of it as "combinations of techniques or operations connected with the practical activity determined by the illocutionary forces of the influencing subject, and chosen by him for specific goals" [55, p. 43]. The background of studying such kinds of speech influence as suggestion, persuasion, neurolinguistic programming allows to focus on the researching of the phenomenon of manipulation.

Exerting the manipulative influence over the addressee has been highlighted in a manifold of scientific fields, linguistics in particular. A number of works focus on studying the manipulative influence in the political discourse $[13 ; 17 ; 23 ; 24 ; 25 ; 27 ; 32 ; 36 ; 38 ; 42 ; 46 ; 67]$, advertising discourse [30; 68], media discourse [14; 41; 58], marketing discourse [29], fairy-tale discourse [49] and other discourse types. Moreover, manipulation with consideration for the speaker's gender has been covered $[61 ; 62 ; 63]$. Scientific attention has been also paid to verbal and nonverbal characteristics of implementing the strategy of manipulation $[1 ; 6 ; 31 ; 33 ; 37 ; 39 ; 60]$, positive manipulation has been looked into [56]. This being stated proves the constant interest of scholars in this phenomenon and its topicality and applicability for the present-day science. 


\section{Chapter «Philological sciences»}

Researching the linguistic aspects of manipulation views an adult speaker as the subject, i.e. as a fully-grown and developed discursive personality. Analyzing the verbal and nonverbal implementation of speech manipulation at different age-based life stages in children's communication in the English authoritarian discourse of children requires more studying and structural analyzing, which proves the significance of our study. The principal objective of this paper is to demonstrate the tactical variability of the manipulative strategy implementation depending on the age of the communicative partner and the type of relationship the speakers are involved in through the methods of discourse and pragmatic analysis.

In order to reach the objective of this paper the following sequence of methodological steps have been undertaken: underpinning the foundation for studying manipulative influence, exposing the implementation of the manipulation strategy in the authoritarian discourse of children in terms of its tactic variability, lexical, semantic and structural contents in different dialogical situations.

The object matter of this paper is the manipulation tactics in the English authoritarian discourse of children, the subject matter being lexical, semantic and pragmatic characteristics of the tactics.

The analysis of the manipulation strategy proved that not only the tactical and structural arsenal of the manipulation strategy varies according to the situations, but the style of its implementation as well. E. Shostrom suggests singling out four types of manipulation systems (manipulators): 1) the active manipulator - the one who attempts at controlling the recipient through applying active methods; 2) the passive manipulator - the one who overtakes the opponent by pretending to be weak and helpless; suffering a defeat in fact gives him an advantage, i.e. helps reach the chosen objective; 3 ) the competitive manipulator - the one who takes life as competition, and always switches between the active and passive role; 4) the indifferent manipulator - the one who plays indifference and unconcern; it is typical for wedded couples [57].

The manipulative capability as a trait of a discursive personality manifests "relations with other speakers not on even terms, but as if they are just objects" [18, p. 221]. Thus, the manipulator violates the norms of harmonious communication, paying too little respect to the recipient and trying to control him against his will. The chosen definition and the characteristics of implementing manipulation in interpersonal communication are to be given further. 


\section{Verbal manipulation in linguistic studies}

Manipulation is viewed in this paper as one of the strategies in the authoritarian discourse. According to the illocutionary objective of the speaker, three types of authoritarianism are singled out: 1) authoritarian manipulation, 2) authoritarian pressure and 3) authoritarian domination [33].

Within the scope of our linguistic interest the authoritarian manipulation is interpreted as a hidden kind of psychological and communicative influence over the recipient, a group of people or a large number of speakers the implementation of which leads to "modifying the interconnected algorithms and modes of the way their conscience, sub-conscience and non-conscience work" [26, p. 14]. It is achieved through the meeting of the speaker's perlocutionary objectives $[60$, p. 139] and leads to the addressee modifying his existent intentions, knowledge and skills or having new ones which do not match the currently present knowledge $[1$, p. $7 ; 7$, p. $19 ; 14$, p. 10; 15, p. 59; 21$, p. $8 ; 34$, p. $5 ; 43 ; 44]$. In this respect speech manipulation is exercised through the skillful applying of language resources for realizing impact on the recipient's cognitive and behavioral activity the result of which is a cognitive dissonance [21, p. 6]. Apart from this, it changes the rational, emotional and psychological state of the person's evaluation and behavior motivation $[13$, p. $359 ; 31$, p. $24 ; 54$, p. 103]. The manipulator plans and foresees the addressee's speech behavior judging from his own knowledge and motives [63, p. 188], and asserts himself placing his interlocutor at a lower status level than himself in a specific communicative situation [54, p. 52].

The discourse manifestation of manipulation lies in using the characteristic features of the ideological discourse, the tactics of emphasizing "our" good and "their" bad in particular [13, p. 359]. The manipulator combines various verbal means for expressing "a certain contextual, thematic, functional, pragmatic, formally stylistic content guided by a global stylistic objective" [63, p. 188]. Manipulation can be both verbal and nonverbal (actional), conscious and non-conscious/intuitive [35, p. 359; 43, p. 171-174; 48 , p. 22]. The above-mentioned types of manipulation are all typical of the English authoritarian discourse of children. Their implementation takes place through applying manipulation tactics and techniques.

Amanipulative tactic is a speech action, a manifold of techniques to implement manipulation for deluding the addressee in a hidden way and encouraging him to act for the addresser's benefit. Thus, a manipulation technique is a way to create an utterance which implements a manipulation tactic [31, p. 48; 40, p. 34]. 


\section{Chapter «Philological sciences»}

Looking into the phenomenon of manipulation L.Je. Sorokina [61, p. 18] asserts that speech manipulation is a peculiar phenomenon which can be built up differently depending on the conditions of its implementation (the type of discourse - pedagogical, military, medical, ecological, family discourse; the age of the interlocutors - children, teenagers, adults, people of middle age; the level of their communicative competence and life experience; the type of relationships they are involved in - family members, close friends, colleagues, acquaintances who barely keep in touch quite seldom; gender identity;). The researcher claims there to be three lines of strategic manipulation behavior, i.e. three macro-strategies: cooperative, regulatory and conflicting. The tactics used for their implementation may acquire a manipulative nature while applied in the process of communication. The pragmatic objective of having a one-sided advantage and control over an addressee is to be achieved.

\section{The children's tactics of manipulation}

The manipulation strategy in the authoritarian discourse of children is implemented by means of four principal tactics: appealing to the rational and emotional spheres of the addressee; manipulating the addressee through the intermediated influence over a third person; creating an idea of a reward; the tactic of pretended kindness. Each of the tactics is reflected in applying manipulation techniques (shifting responsibility, generalization, negative reference to a third person and referring to him through influential sources or artifacts) for resolving the task of the tactic [4;24, p. 125]. Manipulation moves, which are units of a lower level, help to construct and implement a certain technique.

The tactic of appealing to the rational sphere or emotions of the addressee is actualized through appealing to the person's logical thinking or basic emotions - compassion, fear, guilt, etc. The choice of the tactical arsenal depends on the age of both an addresser and addressee. The tactic is typical of children of different age - from preschool to teenage.

The main cause which triggers pre-school children's desire to try themselves at controlling adults or older children by means of language is considered to be their inequality in speech interaction [44, p. 346]. Under the circumstances when the role of the older speaker is generally understood as a dominant one in comparison with that of a preschooler, and the communication is vertical, children tend to refuse the direct implementation 
of their plans and try to modify the cognitive and behavioral mindsets of the adults through speech manipulation [44, p. 347].

With pre-school children, actional (nonverbal) manipulation is typical. It lies in applying nonverbal means like tears, hysterics, sneezing which are used alongside with verbal means. As manipulation is generally too complicated for pre-school children, considering their level of speech development, manipulation occurs through the usage of any available means of language/paralanguage at the current stage. During early childhood, actional manipulation is mostly non-conscious and is applied as an empiric way of gaining the desired things.

The analysis of the factual material showed the results that are in agreement with the opinion of A.A. Osipova [43] as to actional manipulation being characteristic of preschool children. It is typical for pre-schoolers when the verbal elements put into practice earlier have not yielded any desirable result. For 4-year-old Ramona it is a tragedy that her guests refuse to eat the biscuits because of her silly joke. In order to put pressure on the other children the whole nonverbal arsenal is applied - kinesic (thrusting her handful of cookies at the children; threw the fig Newtons at her guests; banging her fists on the floor), proxemic (threw herself on the floor) and prosodic (yelled; howled):

"You eat these," Ramona yelled, thrusting her handful of cookies at the children, who backed away. Ramona stamped her feet and screamed. Then she threw the fig Newtons at her guests as hard as she could. "My mother won't let me eat worms!" shouted a little boy. Ramona threw herself on the floor and kicked. "This is my party! They're supposed to eat the refreshments!" Ramona howled, banging her heels on the floor [11, p. 140-142].

Thus, opting for this tactic in talking with the children of the same age mostly does not guarantee its being successful, which leads to a communicative failure and prevents a further cooperative dialogue.

The technique proves to be more efficient while applying it in communication with older children:

Murph jerked the papers away from Ramona. Kicking and howling, she threw herself on the sidewalk. "You give me back my papers!" she screamed. "They aren't your papers," said Murph, his face and ears so crimson with embarrassment that Henry almost felt sorry for him, because he knew how exasperating Ramona could be... [9, p. 176]. Being physically, intellectually and verbally unable to withstand Murph, who is seven years 


\section{Chapter «Philological sciences»}

older than Ramona, the latter one activates unconsciously the only efficient mechanism in her opinion - constructing the emotional tension of the situation by means of excessively expressive prosodic behaviour (screamed) and changing the space dimension of communication (threw herself on the sidewalk). The first attempts at manipulating others are made by children non-consciously, mimicking adults, using the prearranged speech patterns learnt from them, and afterwards, as the children grow older, the level of conscious manipulation actions grows [45, p. 206-207].

The success of this behavior type is guaranteed by direct influence over the cognitive and emotional spheres of the older child who has a bigger life experience and takes into account the socially accepted opinion helping the younger and the weaker, and therefore feels guilty and does not wish to "lose a face" looking like a bully who offends a younger child. The manipulator creates a situation in which his "victim" either yields to the undesirable demand or risks suffering social embarrassment [3, p. 26-27]. Murph's psychophysiological reaction proves his embarrassment over Ramona's behavior (his face and ears so crimson with embarrassment).

Children start acquiring the skills of conscious manipulation, according to A. A. Osipova, at the early preschool age [43, p. 171]. The conscious appealing to the addressee's emotional sphere prevails with middle- and high- school children. The role of the active manipulator may be carried out by the child both younger and older than the child who is the object of manipulation [13, p. 362]. Some researchers claim [3, p. 27; 35, p. 358] that manipulating the recipient to one's own advantage does not necessarily depend on the speaker's having a higher social position or possessing certain resources (in communication we interpret them as an advantage through being older than the interlocutor, a higher social status and larger life expertise). Nevertheless, the latter may be of help for the manipulator while exerting influence over the addressee.

Thus, in communication of siblings the manipulating child who is younger than the recipient may reach his objective through activating the feeling of responsibility and guilt of the older sibling. Phoebe tries to prevent her brother from leaving home. The girl refuses to go back to school ever again. The initial move includes revealing her hurt feelings because of his wish to leave her. They are explicated by means of a kinesic nonverbal component (took off my red hunting hat - the one I gave her-and practically chucked it right in my face) and a shift in the spacial orientation 
towards the recipient (Then she turned her back on me again) as a way of increasing the influential effect. A pejorative directive (so shut up!) adds to enlarging the influence on the elder brother, though being not typical for the communication of siblings and it shakes him down most:

She wouldn't answer me. All she did was, she took off my red hunting hat - the one I gave her-and practically chucked it right in my face. Then she turned her back on me again. "Come on, hey. I'll walk you back to school," I said. "I'm not going back to school." I didn't know what to say when she said that. I just stood there for a couple of minutes. "You have to go back to school. You want to be in that play, don't you? You want to be Benedict Arnold, don't you?" "No." "Sure you do. Certainly, you do. C'mon, now, let's go," I said. "In the first place, I'm not going away anywhere, I told you. I'm going home. I'm going home as soon as you go back to school. First, I'm gonna go down to the station and get my bags, and then I'm gonna go straight -" "I said I'm not going back to school. You can do what you want to do, but I'm not going back to school," she said. "So shut up. "It was the first time she ever told me to shut up. It sounded terrible. God, it sounded terrible. It sounded worse than swearing [52, p. 111].

A higher level of complexity of the verbal manipulation is inherent in the speech of middle- and high-school children. Unlike a younger child manipulating an older than himself speaker, in the manipulation of the same-aged children the verbal means while appealing to the recipient's ratio and emotions become more branched, relevant and fundamental. The implementation of the tactic requires more moves and techniques, which is conditioned by quite a mature level of logical mechanisms of implicating and the acquired life experience of the speaker [64, p. 20]. It allows easier decoding of the intention and preventing manipulation.

A middle-school child becomes argumentative, comprises discourse markers of encouragement and drawing attention to the problem, pushing the addressee towards making a decision suitable for the manipulator. A stepby-step argumentation implements the technique of shifting responsibility $[13$, p. 368]. Usually, as O. H. Zvjerjeva asserts, in this way the infantilism of a younger child is manifested in comparison with an older child, thus demonstrating the dependency of the former on the latter [68, p. 179]. This technique is applied, though, among children of the same age as well, when speakers experience fear because of the things done and do not dare to undertake hard decisions: 
“C'mon, Lonnie -”. “Look, we can go back and forth forever. So I'm just going to tell you: I'm not killing that bird. So either you're going to do it, or we're going to leave the bird out here to die on its own. Those are the only two possibilities, okay?" So I walked up to the bird [20, p. 10].

Activating Julian's compassion his friend Lonny talks him into killing the injured pigeon. All the previously applied tactics proved inefficient, the boy decides to increase the categoricalness of his utterances with the help of a sentence which directly demonstrates his intention (so I'm just going to tell you). It is expressed by a pair conjunction of choice (so either you ...or). The effect is enforced with the help of "emotional blackmailing" [37, p. 75] - describing horrible consequences of Julian's passivity (leave the bird out there to die on its own) and an attributive intensifier with a limiting meaning (the only two possibilities).

Among the techniques resorted to by a child in order to encourage the speaker of the same age to do the desirable actions, the manipulator often uses appealing to the rational sphere of the addressee. Having gained enough skills and knowledge about the world around and the norms ruling the society, the child may implement the generalization technique $[13$, p. 370$]$ through appealing to the speaker's gender identity. It is most common for utterances directed at the members of the opposite sex [61, p. 9]:

Malee has been silent this entire time. Seeing a moment, she speaks up.

MALEE: I'm thirsty. (to Leonard) Can you get us some drinks?

LEONARD: Why me?

MALEE: Because it's the gentlemanly thing to do.

JACOB: I'll get the drinks

MALEE: I'll go with you.

Leonard looks to Jacob.

LEONARD: Fine, I'll get the drinks.

Leonard exits [8, p. 62].

Trying to talk face-to-face with Jacob, Malee asks Leonard for a drink. The stimulus to act is the girl's referring to the stereotypical man's role which means being polite and helpful whenever necessary. The objective is reached by using a simple generalizing sentence (it's the gentlemanly thing to do) with an argumentative marker (because).

Manipulating the addressee collectively is also worthy of scientific attention. In it the manipulating speakers "attack" the addressee in sequence. The step-bystep structure based on turn-taking may introduce the tactic of creating a valuable 
object/reward actualized by value-based markers - emotionally intensive lexemes belonging to the valuable axiological field of a person [39, p. 122]:

Just as Gina was about to tell us what we already knew, she spotted something that made herjaw clamp like a clam. The Cabinet were approaching! If the rest of the school had not taken them so seriously, I would have laughed then, because they walked like a movie mean-girl gang, with heads held high and each with one hand (the right) in her blazer pocket. Brodie acknowledged Katie and me by giving us a small nod that barely tilted her chin. Then she turned to Gina. "Hey there, Regina. We hear you've been going around the school telling all and sundry that Amber has damaged your good name." She actually used the words "all and sundry", Linh. "Oh yeah?" demanded Gina, but her voice was fearful. "Who told you that?" "It doesn't matter who told who what." That was Chelsea - she was less articulate. "If you have a problem with any of us, you should have the guts to say it to our faces." "Yeah," said Amber. "I thought we were friends." Gina looked stunned: she'd never so much as contemplated the possibility that the Cabinet would consider her a friend. "I'm hurt that you've been backstabbing me, Gina," said Amber. "I thought that, as friends, we could joke around about stuff like that. I didn't mean it! If anyone is the slut, it is obviously me." Gina was even more flabbergasted [50, p. 22-23].

Some students of an elite girls' school play around Gina. Their objective is to indicate to the girl where she rightfully belongs, from their point of view. By conjuring up an image of a reward in the interlocutor's mind, the addresser of the tactic constructs his discourse around it and a potential chance of getting this reward.

Not only an object or an event may be presented as desirable. It may be a possibility to identify oneself as a member of a certain social group which is, for instance, separated from others by the status distance as it is demonstrated in the fragment above. The manipulation begins with the move of presenting the fuzzy information (We hear you've been) in an accusation sentence joined by a hyperbolized idiomatic expression [13, p. 373] (all and sundry) and (damaged your good name). The next move of avoiding the direct answering the question (It doesn 't matter who told who what) and a conditional sentence with an illocution of reproach are preparatory before the main step - manipulating through appealing to Gina's emotions (I'm hurt) by using the metaphor (You've been backstabbing me) and the syntactic repetition combined with the lexeme representing 


\section{Chapter «Philological sciences»}

values (I thought we were friends; I thought that as friends). The latter is regarded by D. S. Muhortov as a syntactic transformation of concentrating attention on the intention which the speaker wishes to highlight [39, p. 120]. The final move is applying an antithesis by means of the lexical unit denoting a valuable idea/thing (friends) and a pejorative word (slut).

The complexity of tactic structures varies depending on the age of the addressee of manipulative influence. Unlike the multi-step structure of manipulation in the communication of middle- and high-school children, in case of manipulating the speaker with whom the addresser has a substantial age difference, especially if he belongs to the nuclear zone of the discursive surrounding [59], the implementation of the tactic does not require any extra moves. Thus, the addresser may reach his objective in one or two moves only. The most typical element of the syntactic level is the pattern of a complex sentence with a cause-and-effect connection (If you ....I will...):

"We're going to the store, Kitty", I say. She's lying on the floor propped up on her elbows. ..." don't want to come. I want to watch my shows." "If you come, I'll let you pick out an ice cream." Kitty gets to her feet [22].

Another syntactic pattern consists of a simple interrogative incomplete sentence. An informal question of the lowered register (Wanna see?) together with an indefinite pronoun (something) awake Gordie's curiosity and stimulate his wish to find out the information which is interesting for him at the moment:

"Gordie! You wanna see something?" "Sure, I guess so. What?" "Come on down here first." He pointed at the narrow space between the Blue Point Diner and the Castle Rock Drug Store. "What is it, Chris?" "Come on, I said!'” [28, p. 20].

The lexical level marks as the most frequent the verb let, hesitation markers (maybe, perhaps) and inclusion markers, mainly possessive pronouns (our, one of us):

Now that she did not have to read Big Steve unless she wanted to, Beezus felt she would not mind reading it once in a while. 'Come on, Ramona,' she said. 'Maybe I'll have time to read to you before Father comes home.' 'O.K., 'said Ramona happily, as she took Beezus's hand [11, p. 37].

For a younger naughty sister, the hesitation marker (maybe) symbolizes a potential "reward" - reading her favourite book. It all depends upon how politely she behaves. The efficiency of the tactic is proved in Ramona's verbal and nonverbal behaviour (said Ramona happily, as she took Beezus's hand). 
For a younger child it is honour to belong with the company of older children and be identified as one of them:

Look at me, man. Wanna be in our gang? Prove yourself, then. Go on. Go on. (pushes him closer) [66, 1:04:00].

It is exactly the wish of a group identification, belonging to the circle of "my" people [14, p. 112] that the manipulator highlights by using a possessive pronoun (our) and a directive after it (prove yourself).

Manipulating a valuable object/idea proves to be quite a productive tactic. Nevertheless, it may appear inefficient because of making a wrong move at a certain stage of the dialogue:

"Uh . . Ramona, I am going to let you in on a secret. A big secret." Ramona, who liked secrets, looked interested. Henry decided to build it up. "A secret that only boys know." he added impressively. "I don't like boys," Ramona informed him. "Boys are mean" [12, p. 139].

In this fragment the manipulation is based on the gradation principle. Amplified by an intensifying adjective (big), the noun trigger (secret) as a powerful means of exerting influence over the emotional sphere of the child, however, fails to produce the planned impression on the girl while the addresser tries to increase the importance of his words with an attribute (that only boys know). The communicative failure arises due to Ramona's personal likes and dislikes, supported by a clause with a predicative of a negative evaluation (Boys are mean).

Getting a third person involved for an intermediated emotional influence is another manipulation tactic. The implementation occurs through direct referring to a third person who contributes to manipulating actively or passively:

"Ouch," said Austine loudly, as everyone stopped dancing. "Mrs. Spofford, Otis bumped into me." "I did not," said Otis. "You jumped in front of me." "Well, you weren't supposed to be there," said Austine, as she stood up and rubbed herself. "Was he, Mrs. Spofford?" "Otis, run along and play like a good boy," said Valerie Todd Spofford [10, p. 28].

Austine gets rid of the ballet teacher's son who is annoying and distracts everybody in the class. For manipulating an addresser may present a certain amount of information which contradicts the reality [3, p. 11]. Through introducing the modal meaning of obligation (you were not supposed to be there), some changes occur in the adult addressee's conscience. It appeals to the teacher's rational sphere, even though it is not meant for her. The 
vocative (Mrs. Spofford) together with an incomplete repeated question increase the significance of the girl's utterance.

Manipulating the addressee may also take place through influencing a third person's emotions. In this case nonverbal components of communication are of special importance:

And then - "WAHHHH!'” That was Georgia, making like a howler monkey and trying to look like she was crying, which she wasn't, the big faker. Then the worst thing of all happened. I looked up at Mom again. She hadn't moved, but this one tear rolled down her cheek. Then she turned away and walked into the back room without saying anything at all [47, p. 56].

Rafe's younger sister tells their mother inadvertently about her brother's bad behaviour at school. An angry Rafe kicks his sister under the table and gets a bright nonverbal reaction in response (making like a howler monkey та trying to look like she was crying). The mother's nonverbal reaction (She hadn't moved, but this one tear rolled down her cheek. Then she turned away and walked into the back room without saying anything at all) makes the boy feel bad because of the guilt that is activated.

Manipulating through a mediator may be implemented through the technique of its negative presentation by means of undermining authority for others:

RUDY: Leonard, you in?

JACOB: You don't have to go if you don't want to.

RUDY: Don't listen to him. He's a pussy.

Leonard looks between Jacob and Malee.

LEONARD: I'll go.

RUDY: Finally, someone with balls [8, p. 13].

Leonard's tactic move is based on his brother's utterance containing an element which points out the absence of necessity to carry out an action and a volition verb (You don't have to go if you don't want to). Using invectives to characterize Jacob helps convince Leonard, as he does not wish to be associated with being week and unmanly like Jacob. The correct decision is approved by an utterance of praise (finally, someone with balls).

Manipulating the emotional sphere through a mediator may also be implemented by means of referring to a third person with mentioning influential resources or artifacts, such as photos, for instance [13, p. 376] to activate the guilt. The center of the emotional attack on Kenny who is older than Jacob is presented by the photos of his brother who died because of 
Kenny's careless actions. Introducing a narrative element referring to the happy time spent with his brother (Halloween was his favourite holiday; every single Halloween since we were five; how happy he was) puts pressure on the addressee until he begs to stop (Stop it):

A moment later, Kenny enters, looking pissed off. He sits across from Jacob and picks up the phone.

KENNY: What did you say to him?

$J A C O B$ : I thought you'd both like to know that Halloween was Rudy's favorite holiday.

Jacob picks up some pictures and presses them against the glass.

$J A C O B$ : These are pictures from every single Halloween since we were five. You see how happy he was?

KENNY: Stop it [8, p. 51].

A particularly different type of manipulation is embodied when its objective may be treated as a "noble" one [54, p. 104], so called manipulation with the ethical perspective [35, p. 353; 60, p. 137], leading to a "mild" speech influence [55, p. 40]. It implies providing the psychological assistance and support to another person, when rational means of persuasion prove inefficient. In the tactical arsenal of an authoritarian child this tactic may undergo certain changes and be transformed into the tactic of pretended kindness:

Then, seeing how angry Beezus was, she smiled and offered her an apple. "I want to share the apples," she said sweetly. "Oh, no, you don't," said Beezus. "And don't try to work that sharing business on me!" That was one of the difficult things about Ramona [11, p. 105].

Ramona's elder sister caught her red-handed - the girl nibbled at all the apples in the basement of their house and tries to escape punishment. Characteristic features for this tactic are lexemes with an inclusivity component (share the apples) and manipulating the elements of the speaker's nonverbal passport [59], namely faking friendly facial and hand gestures (smiled and offered me an apple).

Pre-schoolers' plans to manipulate older interlocutors often turn out unproductive due to the barely hidden nature of such kind of manipulation. Older addressees easily decode the hidden intention of the child manipulator having broader competence than the latter. This results in switching the communicative roles by both interlocutors in the English authoritarian discourse of children. 


\section{Conclusions}

1. Manipulation is a discourse practice which comprises a cognitive and social dimension and aims at changing the way of thinking, intentions or actions of the addressee without him realizing it. Manipulating the addressee is one of the potential strategies of speech influence resorted to by a discursive personality. The ability to manipulate and implicitly introduce changes into the world perception and the way of thinking of the recipient through verbal and nonverbal means of communication goes through certain stages of formation acquiring its peculiar characteristics.

2. The main tactic arsenal of children while implementing the manipulation strategy comprises the tactic of appealing to the rational and emotional spheres of the addressee, including the involvement of a third person for intermediated manipulative influence (techniques of shifting responsibility; generalization; negative reference to a third person or referring to him through important sources or artifacts); the tactic of creating an image of a reward; the tactic of pretended kindness.

3 . In view of the structural complexity of the tactics, they tend to acquire a more branched structure and their step-by-step implementation with the discursive personality's maturing. The younger the addresser, the simpler the structure of the manipulative tactic is, frequently it is a single-step one. The characteristics of the lexical and semantic contents of the tactics vary in every particular situation. The nonverbal part of the tactics is mostly activated by manipulators of pre-school age, and it is distinct in exceeding expressivity at the levels of kinesic, proxemic and prosodic systems. For middle- and high-school manipulators the verbal part of manipulation is of greater importance.

4. The efficiency of the tactics depends directly on the age of the manipulating child and that of the addressee. Manipulation proves most successful under the circumstances of social disparity, i.e. the age gap between the speakers, which is connected with the stereotypic understanding of what constitutes decent speech behavior of interlocutors with different social status.

Further prospects of the research include tracing lexical, semantic and pragmatic characteristics of the manipulation strategy in the English authoritarian discourse of children with respect to the interlocutors' gender identity. 


\section{References:}

1. Babyre, O. V. (2014). Persuazyvni i manipuljatyvni strateghiji anghlomovnoji komunikaciji z ekotematyky: Avtoref. diss. kand. filol. nauk [Persuasive and Manipulation Strategies of the English Ecological Subject. PhD diss. synopsis]. Kyiv. (in Ukrainian)

2. Bacevych, F. S. (2011). Vstup do linghvistychnoji praghmatyky [Introduction to Linguistic Pragmatics]. Kyiv: Akademija. (in Ukrainian)

3. Billig, M. (2014). Manipulating information and manipulating: examples from the 2004 Portuguese Parliamentary celebration of the April revolution. Critical Discourse Studies, no. 11(2), pp. 158-174.

4. Bjelova, A. D. (2004). Komunikatyvni strateghiji i taktyky : problemy systematyky [Communicative Strategies and Tactics: Systematization Issues]. The Linguistic and Conceptual Pictures of the World, no. 10, pp. 11-16.

5. Cabrejas-Pa N Uelas, A. B. (2017). Manipulation as an ideological tool in the political genre of Parliamentary discourses. Pragmatics, no. 27(2), pp. 207-234.

6. Chabak, L. A. (2017). Movni zasoby politychnoji manipuljaciji [Verbal Means of Political Manipulation]. Problems of Social Work: Philosophy, Psychology, Sociology, no. 1(9), pp. 86-90.

7. Chernyavskaya, V. E. (2012). Diskurs vlasti i vlast' diskursa [The Power of Discourse and the Discourse of Power]. Moscow: FLINTA. (in Russian)

8. Cipriano, A. 12 and Holding. Retrieved from: http://www.dailyscript.com/ scripts/12+and+Holding.pdf

9. Cleary, B. (1990). Henry and the paper Route. New York: Harper Collins.

10. Cleary, B. (2008). Ellen Tebbits. New York: Harper Collins.

11. Cleary, B. (2013). Beezus and Ramona. New York: Harper Collins.

12. Cleary, B. (2014). Henry and the Club House. New York: Harper Collins.

13. Dijk van, T. A. (2006). Discourse and manipulation. Discourse and Society, vol. 17(2), pp. 359-383.

14. Dmytruk, O. V. (2006). Manipuljatyvni strateghiji v suchasnij anghlomovnij komunikaciji (na materiali tekstiv drukovanykh ta Internet-vydanj 2000-2005 rokiv) [Manipulative Strategies in Modern English Communication (on the material of printed and Internet editions of 2000-2005)] (PhD Thesis). Kyiv.

15. Docenko, E. L. (1996). Psihologiya manipulyacii [Pshychology of Manipulation]. Moscow: Progress. (in Russian)

16. Frolova, I. Je., (2009). Strateghija konfrontaciji v anghlomovnomu dyskursi [The Strategy of Confrontation in English Discourse]. Kharkiv: V. N. Karazin Kharkiv National University. (in Ukrainian)

17. Furko, P. (2017). Manipulative uses of pragmatic markers in political discourse. Retrieved from: https://www.researchgate.net/publication/318170377 Manipulative_uses_of_pragmatic_markers_in_political_discourse

18. Furman, $\bar{A}$. V. (2017). Manipuljacija jak fenomen socialjnopsykhologhichnogho tysku [Manipulation as a Phenomenon of Social and Psychological Abuse]. Retrieved from: http://dspace.tneu.edu.ua/bitstream/316497/ 21416/1/220-223.pdf

19. Ghalapchuk-Tarnavsjka, O. M. (2014). Vikova dyferenciacija strateghij i taktyk simejnogho dyskursu (na materiali suchasnoji anghlijsjkoji movy) [Age 


\section{Chapter «Philological sciences»}

Differentiation of Discourse Strategies and Tactics in English Family Discourse (on modern English)]. Burning Issues of English Philology, no. 1, pp. 50-55.

20. Goldblatt, M. (2013). Twerp. New York: Yearling.

21. Golubeva, T. M. (2009). Yazykovaya manipulyaciya v predvybornom diskurse (na materiale amerikanskogo varianta anglijskogo yazyka) : avtoref. dis. ... kand. filol. nauk [Language Manipulation in Pre-Election Discourse (on American English. PhD diss. synopsis]. Nizhnij Novgorod. (in Russian)

22. Han, J. (2014). To All the Boys I've Loved Before. New York: Simon and Schuster Books.

23. Iljnycjka, L. L. (2010). Osoblyvosti vykorystannja sughestyvnykh ta manipuljatyvnykh tekhnologhij $\mathrm{v}$ suchasnomu anghlomovnomu politychnomu dyskursi [Peculiarities of Using Suggestive and Manipulative Technologies in Modern English Political Discourse]. Linguistics of the XXI Century, pp. 115-125.

24. Issers, O. S. (2008). Kommunikativnye strategii i taktiki russkoj rechi [Communicative Strategies and Tactics in Russian]. Moscow: LKI. (in Russian)

25. Kalishhuk, D. M. (2012). Psykholinghvistychni pryjomy movlennjevogho manipuljuvannja u politychnomu dyskursi. «Ghra u prostonarodnistj» [Psycholinguistic Methods of Speech Manipulation in Political Discourse. 'PlaySimpleton Game']. V. N. Karazin Kharkiv Nation. University Messenger, no. 1022, pp. 59-63.

26. Kalita, A. A., Taranenko, L. I. (2012). Rechevaya manipulyaciya: opredelenie, funkciya, mekhanizm realizacii [Speech Manipulation: Definition, Function, Realization Mechanism]. V. N. Karazin Kharkiv National University Messenger, no. 1022, pp. 10-19.

27. Kamil, S. I., Al-Hindawi, F. H. (2017). The Pragmatics of Manipulation in British and American Political Debates. Anchor of Academic Publishing.

28. King, St. (2018). The Body. New York: Scribner.

29. Klishhevsjka, L. Je. (2017). Komunikatyvna strateghija manipuljaciji u marketynghovomu dyskursi [Communicative Strategy of Manipulation in Marketing Discourse]. Scientific Messenger of Humanitarian International University, no. 28, pp. 21-24.

30. Koltysheva, E. Yu. (2008). Manipulyativnoe vozdejstvie v sovremennom reklamnom tekste: nam materiale angloyazychnyh glyancevyh zhurnalov dlya zhenshchin [Manipulative Influence in Modern Advertising Text (on English Glamorous Magazines for Women)]. (PhD Thesis), Yaroslavl'.

31. Kopnina, G. A. (2012). Rechevoe manipulirovanie [Speech Manipulation]. Moscow, FLINTA. (in Russian)

32. Kozhemjachenko, N. (2015). Linghvistychni zasoby manipuljaciji v anghlomovnij politychnij reklami [Linguistic Means of Manipulation in English Political Advertising]. Theoretical and Didactic Philology, no. 20, pp. 197-207.

33. Krjuchkova, P. H. (2003). Avtorytarnyj dyskurs (na materiali suchasnoji anghlijsjkoji movy) [Authoritarian Discourse (on Modern English)] (PhD Thesis), Kyiv.

34. Kuz'mina, T. V. (2017). Effektivnoe manipulirovanie povedeniem cheloveka [Effective Manipulation of Human Interaction]. Moscow: Trade Publishing Corporation 'Dashkov\&Co. (in Russian) 
35. Maillat, D., Oswald, S. (2009). Defining Manipulative Discourse: The pragmatics of cognitive illusions. The International Review of Pragmatics, no 21(2), pp. 348-370.

36. Maselj, Ju. (2012). Zaghaljna kharakterystyka strateghij ta taktyk manipuljuvannja $\mathrm{v}$ anghlomovnij politychnij reklami [General Characteristic of the Strategies and Tactics in English Political Advertising]. Scientific Notes V. Vynnychenko CUSP University, pp. 514-519.

37. Meljnyk, O. M. (2017). Linghvaljni ta paralinghvaljni zasoby aktualizaciji eghojizmu komunikantiv (na materiali anghlomovnoji khudozhnjoji prozy XX-XXI stolitj) [Linguistic and Paralinguistic Means of Actualizing Selfishness of Interlocutors (on English Fiction Prose of XX-XXI Centuries). (PhD Thesis), Lucjk-Zaporizhzhja.

38. Mihalyova, O. L. (2009). Politicheskij diskurs: Specifika manipulyativnogo vozdejstviya [Political Discourse: Peculiarities of manipulative Influence]. Moscow: LIBROKOM. (in Russian)

39. Muhortov, D. S., Krasnova, A. V. (2016). Diskursivnye markery manipulyacii kak realizaciya sub»ektivno-ocenochnogo akta govoryashchego [Discoursive markers of Manipulation Within the Framework of Subjective Evaluation]. Political Linguistics, no. 6(60), pp. 120-125.

40. Navasartyan, L. G. (2017). Yazykovye sredstva i rechevye priyomy manipulyacii informaciej v SMI [Linguistic Means and Techniques of Manipulating Information in Mass Media] (PhD Thesis), Saratov.

41. Nesterenko, O. Ju. (2011). Manipuljaciji u anghlomovnykh ZMI pry vysvitlenni podij na Blyzjkomu Skhodi ta u Pivnichnij Afryci [Manipulation in English Mass Media while Highlighting Events in the Middle East and North Africa]. Linguistics of the XXI Century: New Research and Prospects, pp. 238-244.

42. Nikitina, K. V. (2006). Tekhnologii rechevoj manipulyacii v politicheskom diskurse SMI (na materiale gazet SShA [Techniques of Speech Manipulation in Political Discourse of Mass Media (on newspapers of the USA)]. (PhD Thesis), Ufa.

43. Osipova, A. A. (2015). Manipulirovanije v detskoj rechi: zashita ili napadenije [Manipulation in Children's Speech: Self-defence or Attack?]. The Problems of Ontolinguistics, pp. 171-174.

44. Osipova, A. A. (2016). Kommunikativnye subtaktiki izobrazheniya zhertvy $\mathrm{v}$ rechevom povedenii doshkol'nikov: izobrazhaemaya ugroza zhizni i normal'nomu sushchestvovaniyu [Communicative Subtactics of the Pretendvictim in the Speech Behaviour of Preschoolers: Pretend Threat to Life and Normal Existence]. Ontolinguistics, pp. 346-351.

45. Osipova, A. A. (2017). Osobennosti detskogo rechevogo manipulirovaniya [Peculiarities of Children's Manipulation]. Messenger of $V$. P. Astaphjev Krasnoyarski State Pedagogical University, pp. 206-210.

46. Paljej, T. A. (2018). Ironija jak zasib politychnoji manipuljaciji: linghvistychnyj aspekt (na materiali anghlomovnogho politychnogho dyskursu) [Irony as a Means of Political Manipulation : Linguistic Aspect (on English Political Discourse). V. S. Vernadski Scientific Notes, no. 29(68), pp. 30-35.

47. Patterson, J. (2012). Middle School, the Worst Years of My Life. New York: Little, Brown and Company. 
48. Pavlova, A. V. (2014). Verbal'nye i neverbal'nye sposoby manipulirovaniya v diskurse i vozmozhnosti ih klassifikacij po razlichnym osnovaniyam [Verbal and Noverbal Manipulation in Discourse and its Classifications Based on Different Criteria]. ACTA LINGUISTICA, no. 8, pp. 16-45.

49. Pikalova, A. O. (2012). Taktyky manipuljatyvnoji strateghiji v anghlomovnomu kazkovomu dyskursi [Tactics of Manipulation in English Fairy Discourse]. Zhytomyr State University Messenger, no. 64, pp. 185-189.

50. Pung, A. (2014). Laurinda. Melbourne: Black Inc.

51. Rizun, V. V., Nepyjvoda, N. F., Kornjejev, V. M. (2005). Linghvistyka vplyvu [Linguistics of Influence]. Kyiv: Kyivskyi Universytet. (in Ukrainian)

52. Salinger, J. (2010). Catcher in the Rye. London: Penguin General.

53. Sedov, K. F. (2004). Diskurs i lichnost': evolyuciya kommunikativnoj kompetencii [Discourse and Personality: Evolution of Communicative Competence]. Moscow: Labyrinth. (in Russian)

54. Sedov, K. F. (2016). Obshchaya i antropocentricheskaya lingvistika [General and Anthropocentric Linguistics]. Moscow: Publishing YaSK. (in Russian)

55. Shelestyuk, E. V. (2015). Rechevoe vozdejstvie: ontologiya i metodologiya issledovaniya [Speech Influence: Onthology and Methodology of Research]. Moscow: FLINTA. (in Russian)

56. Shkicjka, I. Ju. (2012). Manipuljatyvna strateghija pozytyvu v ukrajinsjkij movi : avtoref. dys. ... dokt. filol. nauk [Positive Manipulation Strategy in Ukrainian, Doctoral diss. synopsis].

57. Shostrom, E. Anti-Karnegi (2004). [Anti Carnegie]. Retrieved from: http://lib.ru/PSIHO/SHOSTROM/antikarnegi.txt

58. Sidenko, N. G. (2014). Instrumenty movlennjevoji manipuljaciji v anghlomovnij «zhovtij» presi [Instruments of Speech Manipulation in the English Yellow Press]. Notes on Roman and Germanic Philology, no. 2(33), pp. 105-113.

59. Soloshchuk, L. V. (2006). Vzayemodiya verbal'nih i neverbal'nih componentov komunikacii u suchasnomu anglomovnomu discursi [Interaction of Verbal and Non-Verbal Components of Communication in the Modern English Discourse. Kharkiv. (in Ukrainian)

60. Sorlin, S. (2017). The Pragmatics of Manipulation: Exploiting im/politeness theories. Journal of Pragmatics, pp. 132-146.

61. Sorokina, L. Je. (2013). Movlennjeva manipuljacija v suchasnomu anghlomovnomu dialoghichnomu dyskursi: komunikatyvno-koghnityvnyj i ghendernyj aspekty. [Verbal Manipulation in Modern English Dialogical Discourse: Communicative, Cognitive and Gender Aspects, PhD diss. synopsis]. Kyiv: Kyiv National Linguistic University.

62. Sorokina, L. Je. (2014). Movlennjeva manipuljacija ta inshi vydy movlennjevogho vplyvu: terminologhichne rozmezhuvannja ponjatj [Verbal Manipulation and Other Types of Verbal Influence: Differentiation of Terminology]. Scientific Messenger of International Humanitarian University, no. 8, vol. 2, pp. 175-159.

63. Sorokina, L. Je. (2015). Komunikatyvna strateghija vs. manipuljatyvna strateghija [Communciative Strategy vs. Manipulation Strategy]. Burning Issues of Foreign Philology, no. 2, pp. 187-191. 
64. Sternin, I. A. (2012). Osnovy rechevogo vozdejstviya [The Basics of Speech Influence]. Voronezh: Istoki. (in Russian)

65. Suhih, S. A. (1986). Rechevye interakcii i strategii [Speech Interactions and Strategies]. Language Communication and Its Units, pp. 71-77.

66. Watkins, J. Eden Lake. Retrieved from: https://www.springfieldspringfield.co.uk/ movie_script.php?movie=eden-lake

67. Zajceva, M. O. (2012). Zasoby manipuljatyvnogho vplyvu v suchasnomu politychnomu dyskursi (linghvistychnyj aspekt) [Means of Manipulative Influence in Modern Political Discourse (Linguistic Aspect)]. Linguistic Studies, no. 34, pp. 101-104.

68. Zirka, V. V. (2005). Movna paradyghma manipuljatyvnoji ghry v reklami: avtoref. dys. na zdobuttja nauk. stupenja doktora filol. nauk [Lamguage Paradigm of Manipulative Games in Advertising. PhD diss. synopsis]. Kyiv. (in Ukrainian)

69. Zvjerjeva, O. H. (2014). Komunikatyvni strateghiji siblinghiv v anghlomovnomu simejnomu dyskursi [Communicative Strategies of Siblings in the English Family Discourse] (PhD Thesis), Kharkiv: V. N. Karazin Kharkiv National University. 